\title{
Pengaruh Debt to Assets Ratio, Inventory Turnover dan Earningper Share terhadap Harga Saham pada Perusahaan Makanan dan Minuman yang Terdapat di Bursa Efek Indonesia Periode 2014 - 2018
}

\author{
Cristin Natasia Tambunan ${ }^{1}$, Hendro Nababan $^{2}$, Muhammad Fikri Hakim $^{3 *}$, Elsa Elfrida Simatupang ${ }^{4}$ \\ 1,2,3,4 Universitas Prima Indonesia, jl Sekip, Petisah Tengah, Kota Medan \\ *Correspondence email: fikrihakim97@gmail.com
}

\begin{abstract}
Abstrak. Penelitian ini bertujuan menganalisis pengaruh Debt to Assets Ratio, Inventory Turnover dan Earning Per Share Terhadap Harga Saham Pada Perusahaan Makanan Dan Minuman Yang Terdapat di Bursa Efek Indonesia Periode 2014 - 2018. Populasi penelitian yang digunakan sebesar 11 perusahaan dan jumlah sampel sebanyak 55 sampel. Metode penelitianmenggunakan statistik kuantitatif. Teknik analisis data menggunakan uji asumsi klasik. Ujihipotesis dinilai dengan uji regresi linear berganda, uji T, dan uji F. Hasil uji hipotesis koefisiendeterminasi diperoleh nilai Adjusted R Square (R2) sebesar 7\%, maka dapat dikatakan variabel Debt to Assets Ratio (X1), Inventory Turnover (X2) dan Earning Per Share (X3), berpengaruh terhadap Harga Sahamsebesar 7\% dan sisanya sebesar93\% dipengaruhi oleh variabel lain yang tidak terdapat dalam penelitian ini.
\end{abstract}

Kata kunci: Debt to Assets Ratio;Earning Per Share; Inventory Turnover; Harga Saham

Abstract. This study aims to analyze the effect of Debt to Assets Ratio, Inventory Turnover, and Earning Per Share on Stock Prices in Food and Beverage Companies on the Indonesia Stock Exchange for the 2014-2018 period. The population that been used in the research was 11 companies and the number of samples was 55 samples. The research method uses quantitative statistics. The data analysis technique is the classical assumption test. Hypothesis testing with multiple linear regression test, $T$ test, and F-tests. The results of the hypothesis test of the coefficient of determination obtained an Adjusted $R$ Square (R2) value of 7\%, it can be said that the variable Debt to Assets Ratio (X1), Inventory Turnover (X2) and Earning Per Share (X3), affects the stock price by $7 \%$ and the remaining $93 \%$ from other variables not included in this study.

Keywords: Debt to Assets Ratio; Earning Per Share; Inventory Turnover; Stock Price

\section{PENDAHULUAN}

Penilaian harga saham merupakan hal yang sangat penting dan mendasar bagi para investor sebelum melakukan investasi karena saham merupakan salah satu jenis investasi yang menjanjikan untuk para investor. Harga saham sangat ditentukan dari penawaran dan permintaan akan saham itu sendiri. Saham berwujud selembar kertas yang menerangkan bahwa pemilik kertas tersebut adalah pemilik perusahaan yang menerbitkan surat berharga tersebut. Fahmi (2012:81) yang dimaksud dengan saham adalah: "Tanda bukti penyertaan kepemilikan modal/dana pada suatu perusahaan, kertas yang tercantum dengan jelas nilai nominal, nama perusahaan dan diikuti dengan hak dan kewajiban yang dijelaskan kepada setiap pemegangnya, dan persediaan yang siap utuk dijual."

Harga saham merupakan faktor yang sangat penting dan harus diperhatikan oleh investor dalam melakukan investasi karena harga saham menunjukkan prestasi emiten. Pergerakan harga saham searah dengan kinerja emiten, apabila emiten mempunyai prestasi yang semakin baik maka keuntungan yang didapat dan dihasilkan dari operasi usaha semakin besar (Tandelilin, 2010). Harga saham juga menunjukkan nilai suatu perusahaan dan merupakan indeks yang tepat untuk efektivitas perusahaan. Dengan semakin tinggi harga saham, maka semakin tinggi pula nilai perusahaan tersebut dan sebaliknya (Jogiyanto, 2010). Harga saham yang terlalu rendah sering diartikan bahwa kinerja perusahaan kurang baik. Namun bila harga saham terlalu tinggi mengurangi kemampuan investor untuk membeli saham tersebut.

Naik turunnya harga saham di pasar modal menjadi sebuah fenomena yang menarik untuk dibicarakan berkaitan dengan isu naik turunnya nilai perusahaan itu sendiri. Fluktuasi harga saham salah satunya terjadi pada perusahaan subsektor makanan dan minuman yang terdaftar di Bursa Efek Indonesia. Harga saham pada perusahaan ini ada yang mengalami penurunan dari harga saham yang beredar di Pasar Bursa pada periode 2015-2016. Biasanya, turunnya nilai harga saham diakibatkan beberapa faktor misalnya adanya faktor eksternal perusahaan (inflasi, suku bunga dan wabah dll) dan faktor internal perusahaan seperti Earning Per Share,Inventory Turnover dan Debt To Asset Ratio.Berdasarkan data harga saham yang diperoleh dari situs Bursa Efek Indonesia harga saham industri subsektor makanan dan minumanyang di tampilkan pada tabel 1 ini: 
Cristin Natasia Tambunan et al, Pengaruh Debt to Assets Ratio, Inventory Turnover dan Earningper Share terhadap Harga Saham pada Perusahaan Makanan dan Minuman yang Terdapat di Bursa Efek Indonesia Periode 2014 - 2018

Tabel 1. Debt To Assets Ratio, Inventory Turn Overdan Earning Per Share terhadap Harga Saham pada Perusahaan Sub Sektor Makanan Dan Minuman tahun 2015 - 2016

\begin{tabular}{cccccc}
\hline Perusahaan & Tahun & DAR & ITO & EPS & Harga Saham \\
\hline \multirow{2}{*}{ PT.Sekar Laut Tbk } & 2015 & 0,66763 & 9,27571 & 29,0511 & 370 \\
& 2016 & 0,47883 & 9,23294 & 29,8898 & 308 \\
PT.Sekar Bumi Tbk & 2015 & 0,54991 & 12,5368 & 42,8716 & 945 \\
\multirow{2}{*}{ PT.Mayora Indah Tbk } & 2016 & 0,63222 & 6,29818 & 24,0734 & 640 \\
& 2015 & 0,54204 & 8,40429 & 1397,88 & 30500 \\
& 2016 & 0,51516 & 8,64066 & 62,109 & 1645 \\
\hline
\end{tabular}

Sumber : data diolah, 2019

Berdasarkan table diatas, harga saham pada PT. Sekar Laut Tbk terlihat mengalami penurunan di tahun 2016 yang sebelumnya ditahun 2015 sebesar 370 menurun menjadi sebesar 308 dengan nilai DAR dan ITO ikut mengalami penurunan, namun terlihat pada nilai EPS justru mengalami peningkatan yang sebelumnya di tahun 2015 sebesar 29,0511 meningkat di tahun 2016 menjadi 29,8898. Selanjutnya harga saham pada PT. Sekar Sari Tbk terlihat mengalami penurunan juga di tahun 2016 yang sebelumnya di tahun 2015 harga saham sebesar 945 menurun menjadi 640 dan diikuti nilai ITO dan EPS, namun justru nilai DAR mengalami kenaikan yang sebelumnya di tahun 2015 sebesar 0,54991 menjadi 0,63222 di tahun 2016. Dan pada PT. Mayora Indah harga sahamnya mengalami penurunan yang sangat signifikan di tahun 2016 yang sebelumnya di tahun 2015 sebesar 30.500 menjadi 1.645 diikuti juga penurunan nilai DAR dan EPS, namun justru nilai ITO mengaami kenaikan yang sebelumnya di tahun 2015 sebesar 3,404 menjadi 8,6406 di tahun 2016.

Dari penjelasan diatas, terlihat bahwa terjadi ketidakkonsistenan nilai Debt to Asset Ratio, Inventory Turnover dan Earning Per Share yang disebabkan oleh penurunan harga saham. Debt to Asset Ratio merupakan rasio utang yang digunakan untuk mengukur perbandingan antara total utang dengan total aktiva. Dengan kata lain, seberapa besar aktiva perusahaan dibiayai oleh utang atau seberapa besar utang perusahaan berpengaruh terhadap pengelolaan aktiva. Earning Per Share merupakan rasio untuk mengukur keberhasilan manajemen dalam mencapai keuntungan bagi pemegang saham. Perputaran persediaan (Inventory Turnover) adalah perbandingan antara harga pokok penjualan dengan rata-rata persediaan suatu perusahaan. Perputaran persediaan yang semakin meningkat menunjukkan tingkat perputaran dana yang tertanam pada persediaan juga tinggi. Perputaran persediaan yang lambat menunjukkan lamanya persediaan tersimpan diperusahaan, sehingga hal ini dapat memperbesar biaya persediaan, dan akan mempengaruhi laba perusahaan (Fitri, 2013).

\section{METODE}

Penelitian ini menggunakan pendekatan kuantitatif yaitu, penelitian ilmiah yang sistematis terhadap bagianbagian dan fenomena serta hubungan-hubungannya yang berguna untuk menganalisis hubungan-hubungan antara satu variabel dengan variabel lainnya atau bagaimana suatu variabel mempengaruhi variabel lainnya (Umar, $2003: 17)$.

Populasi dalam penelitian ini adalah perusahaan subsektor makanan dan minuman sebanyak 18 perusahaan. Data sampel dengan menggunakan teknik purposive sampling. Adapun kriteria tersebut adalah sebagai berikut:

1. Perusahaan subsektor makanan dan minuman yang terdaftar di Burasa Efek Indonesia selama tahun 2014-2018.

2. Perusahaan yang mempublikasikan laporan keuangannya secara berurutan periode 2014-2018.

Dari total jumlah 18 perusahaan populasi diseleksi menjadi data sampel yang digunakan dalam penelitian adalah 11 perusahaan dikalikan dengan 5 periode maka total sampel adalah 55 sampel mulai tahun 2014-2018.

\section{Teknik Pengumpulan Data}

Teknik pengumpulan data yang akan digunakan dalam penelitian ini adalah teknik dokumentasi. Dokumentasi menurut (Sugiyono, 2015: 329) adalah suatu cara yang digunakan untuk memperoleh data dan informasi dalam bentuk buku, arsip, dokumen, tulisan angka dan gambar yang berupa laporan serta keterangan yang dapat mendukung penelitian. Dokumentasi digunakan untuk mengumpulkan data kemudian ditelaah.Dokumentasi yang digunakan dalam penelitian ini adalah berupa laporan keuangan perusahaan sampel setiap periode penelitian (2015 s/d 2018).

Pengujian terhadap hipotesis dalam penelitian ini menggunakan analisis regresi berganda. Analisis regresi berganda digunakan untuk mengukur pengaruh atau hubungan variabel independen dengan variabel dependen. Model persamaan analisis regresi dalam penelitian ini adalah sebagai berikut:

$$
\begin{array}{ll}
\mathbf{Y}=\boldsymbol{\alpha}+\boldsymbol{\beta 1 X} \mathbf{X} & +\boldsymbol{\beta 2 X} \mathbf{2}+\boldsymbol{\beta 3 X} \mathbf{X}+\mathbf{e} \\
\text { Keterangan: } & \\
\mathrm{Y} & =\text { Variabel terikat (dependen) } \\
\mathrm{X}(1,2,3, \ldots) & =\text { Variabel bebas (independen) } \\
\mathrm{a} & =\text { Konstanta } \\
\mathrm{b}(1,2,3, \ldots) & =\text { Nilai koefisien regresi }
\end{array}
$$


Cristin Natasia Tambunan et al, Pengaruh Debt to Assets Ratio, Inventory Turnover dan Earningper Share terhadap Harga Saham pada Perusahaan Makanan dan Minuman yang Terdapat di Bursa Efek Indonesia Periode 2014 - 2018

\section{HASIL DAN PEMBAHASAN \\ Statistik Deskriptif}

Menurut Ghozali (2006: 19), "statistik deskriptif memberikan gambaran atau deskripsi suatu data yang dilihat dari nilai rata-rata (mean), standar deviasi, varian, maksimum, minimum, sum, range, kurtosis, dan skewness (kemencengan distribusi)".terkait ataupun dapat membandingkan dengan penelitian sebelumnya.

\section{Hasil Uji Asumsi Klasik}

Uji asumsi klasik digunakan untuk menguji apakah dalam model regresi tidak terjadi penyimpangan yang cukup serius dari asumsi-asumsi yang telah ditetapkan.

\section{Uji Normalitas}

Uji statistik yang digunakan dalam penelitian ini adalaha uji Kolmogorov-Smirnov (K-S) dengan membuat hipotesis :

Ho: data residual berdistribusi normal

Ha: data residual tidak berdistribusi normal

Pedoman yang digunakan dalam pengambilan keputusan antara lain:

1. Jika nilai signifikan lebih besar dari 0.05 maka Ho diterima.

2. Jika nilai signifikan lebih kecil dari 0.05 maka Ho ditolak

Tabel 2. Hasil Uji Kolmogrov-Sminrov -Test One-Sample Kolmogorou-Smirnov Test

\begin{tabular}{|ll|r|}
\hline & & $\begin{array}{r}\text { Unstandardiz } \\
\text { ed Residual }\end{array}$ \\
\hline Normal Parameters & Mean & 55 \\
& Std. Deviation & 0000000 \\
Most Extreme Differences & Absolute & $4.08965473 \mathrm{E} 3$ \\
& Positive & .101 \\
& Negative & .101 \\
Kolmogorov-Smirnov Z & & -.077 \\
Asymp. Sig. (2-tailed) & & .747 \\
\hline
\end{tabular}

a. Test distribution is Normal.

Sumber: Data diolah

Berdasarkan hasil uji statistik dengan model Kolmogorov-Smirnov yang terdapat dalam tabel 2 di atas, dapat dilihat bahwa Asymp. Sig. (2-tailed) sebesar $0,632>0,05$. Dengan demikian maka Ho diterima dan Ha ditolak, artinya data residual telah berdistribusi normal.Uji normalitas selanjutnya dilakukan dengan analisis grafik melalui grafik histogram dan normal probability plot. Pada grafik histogram, data yang mendekati distribusi normal adalah distribusi data yang berbentuk seperti gunung dengan kaki gunung yang simetris baik kanan maupun kiri. Sementara pada grafik normal probability plot (normal P-P Plot), sebuah data dinyatakan berdistribusi normal apabila titik-titik datanya tidak menceng ke kiri atau ke kanan, melainkan menyebar di sekitar garis diagonal.

\section{Histogram}

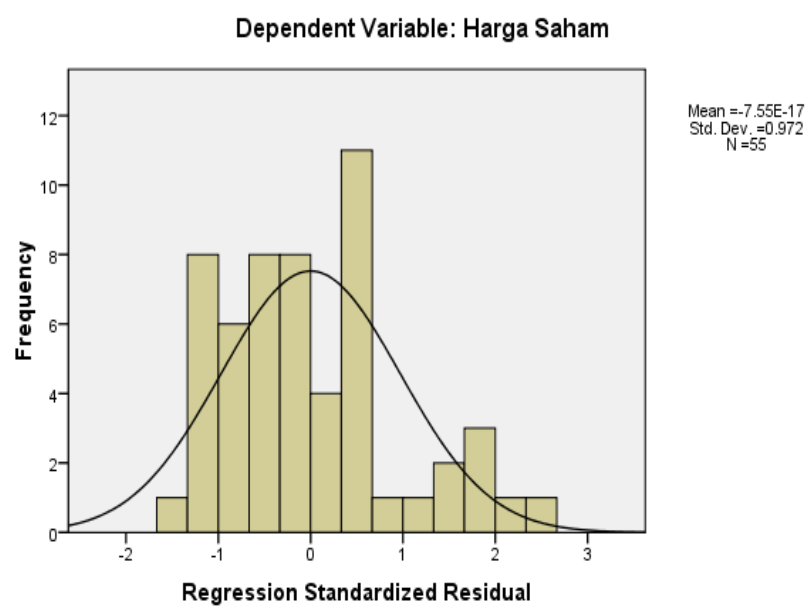

Gambar 1. Grafik Histogram

Normal P-P Plot of Regression Standardized Residual

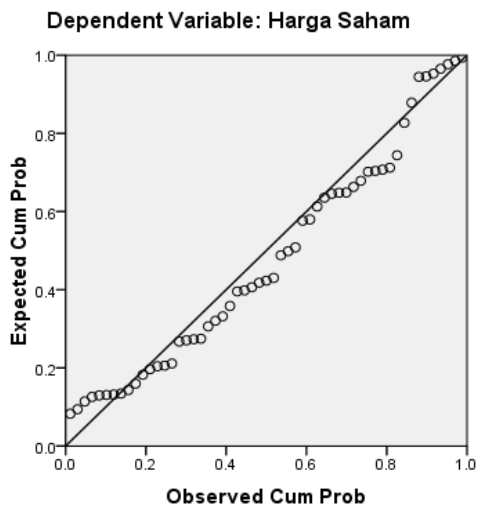

Gambar 2. Grafik Normal P-Plot

Dari grafik histogram di atas, terlihat bahwa distribusi data simetris pada bagian kiri dan kanan. Sementara pada grafik normal P-Plot, terlihat bahwa titik-titik menyebar di sekitar garis diagonal. Dengan demikian, maka dapat disimpulkan bahwa pola distribusi data adalah normal.

\section{Uji Heteroditas}

Uji heterokedastisitas bertujuan untuk melihat apakah dalam model regresi terjadi ketidaksamaan variabel dari residual satu pengamatan ke pengamatan yang lain. Jika varian dari residual satu pengamatan ke pengamatan yang lain tetap, maka disebut homoskedastisitas sementara jika berbeda disebut heteroskedastisitas. Model regresi yang baik adalah tidak terjadi heteroskedastisitas. 
Scatterplot

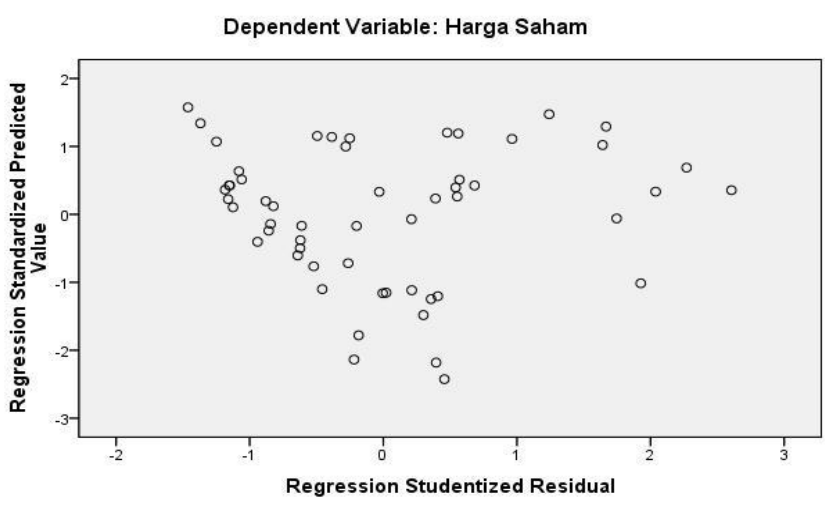

Gambar 4. Uji Heteroditas

Dari gambar scatterplot di atas, terlihat bahwa titik-titik menyebar secara acak dan tidak membentuk pola tertentu atau tidak teratur.Di samping itu, titik-titik tersebut menyebar di atas dan di bawah angka 0 pada sumbu Y. Hal ini menunjukkan bahwa tidak terjadi heteroskedastisitas pada model regresi sehingga model ini layak dipakai dalam penelitian ini.

\section{Pembahasan \\ Pengaruh Debt to Asset Ratio terhadap Harga Saham}

Berdasarkan hasil uji parsial (uji t), dapat disimpulkan bahwavariabel independen Debt to Asset Ratio(DAR) secara parsial tidak berpengaruh signifikan terhadap harga saham.Hal ini sejalan dengan hasil penelitian yang di lakukan oleh Jaqualine O.Y. Ponggohong, Sri Murni dan Marjam Mangantar (2016) tentang pengaruh kinerja keuangan terhadap harga saham dimana variabel DAR tidak berpengaruh signifikan terhadap harga saham dan penelitian Vasta (2013) tentang pengaruh Earning Per Share, Return On Assets, Net Profit Margin, Debt to Assets Ratio dan Long Term Debt to Equity Ratio terhadap Harga Saham pada perusahaan Perdagangan yang terdaftar di Bursa Efek Indonesia dimana variabel DAR berpengaruh negatif dan tidak signifikan terhadap harga saham perusahaan.

Namun penelitian hasil penelitian ini tidak sejalan dengan penelitian Novita Putri Anindita (2017) tentang Pengaruh CR, ROE, ROA, DAR, Dan DER terhadap harga saham pada perusahaan manufaktur yang listing di Bursa Efek Indonesia dimana variable DAR berpengaruh signifikan terhadap Harga Saham.

\section{Pengaruh Inventory Turnover terhadap Harga Saham}

Berdasarkan hasil uji parsial (uji t), dapat disimpulkan bahwavariabel independen Inventory Turnover(ITO) secara parsial tidak berpengaruh signifikan terhadap harga saham.

Hal ini sejalan dengan hasil penelitian yang di lakukan oleh Indra Setiyawan (2014) tentang Pengaruh
Current Ratio, Inventory Turnover, Time Interest Earned Dan Return On Equity Terhadap Harga Saham Pada Perusahaan Manufaktur Sektor Barang Konsumsi Yang Terdaftar Di Bei Periode 2009-2012 dimana variable ITO tidak berpengaruh terhadap Harga Saham pada perusahaan manufaktur sektor barang konsumsi yang terdaftar di BEI 2009-2012.

Dan sejalan juga dengan penelitian Ririn Dwi Jayanti (2017) tentang Pengaruh Inventory Turnover, Fixed Asset Turnover, Return On Asset Dan Return On Equity Terhadap Harga Saham Pada Perusahaan Properti Dan Real Estate yang terdaftar di Bursa Efek Indonesia dimana variable ITO tidak berpengaruh terhadap Harga Saham Pada Perusahaan Properti dan Real Estate yang terdaftar di Bursa Efek Indonesia.

\section{Pengaruh Earning Per Share terhadap Harga Saham}

Berdasarkan hasil uji parsial (uji t), dapat disimpulkan bahwavariabel independen Earning Per Share (EPS) secara parsial berpengaruh positif signifikan terhadap harga saham.

Hasil penelitian ini sejalan dengan hasil penelitian yang dilakukan oleh Fica Marcellyna dan Titin Hartini (2012) tentang pengaruh Earning Per Share (EPS) terhadap harga saham LQ-45 Di Bursa Efek Indonesia (BEI) dimana variable EPS memiliki pengaruh terhadap harga saham perusahaan yang terdaftar dalam LQ-45 di BEI.

\section{SIMPULAN}

Berdasarkan hasil penelitian pada bab sebelumnya, maka kesimpulan yang dapat diperoleh dari penelitian ini adalah:

1. Debt to Asset Ratio secara parsial tidak berpengaruh signifikan terhadap Harga Saham pada perusahaan Subsektor makanan dan minuman yang terdaftar di Bursa Efek Indonesia Tahun 2014-2018.

2. Inventory Turnover secara parsial tidak berpengaruh signifikan terhadap Harga Saham pada perusahaan Subsektor makanan dan minuman yang terdaftar di Bursa Efek Indonesia Tahun 2014-2018.

3. Earning Per Share secara parsial berpengaruh positif signifikan terhadap Harga Saham pada perusahaan Subsektor makanan dan minuman yang terdaftar di Bursa Efek Indonesia Tahun 2014-2018.

4. Dari hasil pengujian yang dilakukan secara simultan bahwa Debt to Asset Ratio, Inventory Turnover, danEarning Per Sharetidak berpengaruh signifikan terhadap Harga Saham pada perusahaan Subsektor makanan dan minuman yang terdaftar di Bursa Efek Indonesia Tahun 2014-2018 dengan nilai Adjusted R Square sebesar 0,07 atau sama dengan $7 \%$. 
Cristin Natasia Tambunan et al, Pengaruh Debt to Assets Ratio, Inventory Turnover dan Earningper Share terhadap Harga Saham pada Perusahaan Makanan dan Minuman yang Terdapat di Bursa Efek Indonesia Periode 2014 - 2018

\section{DAFTAR PUSTAKA}

Ade Gunawan \& Sri Fitri Wahyuni. 2013. Pengaruh Rasio Keuangan Terhadap Pertumbuhan Laba Pada Perusahaan Perdagangan Di Indonesia. Jurnal Manajemen \& Bisnis Vol 13 No. 01 ISSN 1693-7619.

Eduardus Tandelilin, 2001, Analisis Investasi dan Manajemen Portofolio Edisi Pertama, Yogyakarta: BPFE-Yogyakarta

Fahmi, Irham. 2012. Analisis Kinerja Keuangan , Bandung: Alfabeta

Fica Marcellyna \& Titin Hartini. 2012. Pengaruh Earning Per Share (EPS) Terhadap Harga Saham Lq-45 Di Bursa Efek Indonesia (BEI). Jurnal Akutansi. STIE MDP

Ghozali, Imam. 2016. Aplikasi Analisis Multivariete Dengan Program IBM SPSS 23 (Edisi 8). Cetakan ke VIII. Semarang : Badan Penerbit Universitas Diponegoro.

Husein Umar. 2003.Metodologi Penelitian Untuk Skripsi dan Tesis Bisnis,Jakarta : PT. Gramedia Pustaka.

Indra Setiyawan. 2014. Pengaruh Current Ratio, Inventory Turnover, Time Interest, Earned, Dan Return On Equity Terhadap Harga Saham Pada Perusahaan Manufaktur Sektor Barang Konsumsi Yang Terdaftar Di BEI Periode 2009-2012. Jurnal Nominal Vol IIII. No 1. Universitas Negeri Yogyakarta: Jurusan Pendidikan Akutansi

Jaqualine, Sri, \& Marjam. 2016. Pengaruh Kinerja Keuangan Terhadap Harga Saham (Studi Pada Perusahaan Ritel yang Terdaftar di BEI Tahun 2010-2013). Jurnal Berkala Ilmiah Efisiensi Vol 16. No 01. Universitas Sam Ratulangi: Manado

Jogiyanto, 2008, Teori Portofolio dan Analisis Investasi Edisi Kelima, Yogyakarta: BPFE-Yogyakarta

Novita Putri Anindita. 2017. Pengaruh CR, ROE, ROA, DAR, dan DER terhadap harga saham pada perusahaan manufaktur yang listing di Bursa Efek Indonesia. Universitas Muhammadiyah Surakarta

Ririn Dwi Jayanti. 2012. Pengaruh Inventory Turnover, Fixed Asset Turnover, Return On Asset Dan Return On Equity Terhadap Harga Saham Pada Perusahaan Properti Dan Real Estate yang terdaftar di Bursa Efek Indonesia. Jurnal Produktifitas (JPRO) ISSN 2355-1038. Universitas Muhammadiyah Pontianak: Pontianak Sugiyono. 2016. Metode Penelitian Administrasi Dilengkapi dengan Metode R\&D. Bandung: CV Alvabeta 